\title{
Experiences and Perceptions of the Parents of Children with Autism in Relation to Involvement in Kindergarten and the Impact on Them
}

\author{
Dr. Artur Rada \\ Faculty of Social Sciences, University of Tirana, Tirana, Albania \\ arturrada@yahoo.com \\ Dr. Irida Agolli (Nasufi)
}

Faculty of Social Sciences, University of Tirana, Tirana, Albania

iagolli@yahoo.com

Artenida Duraku

Faculty of Social Sciences, University of Tirana, Tirana, Albania

artenidaduraku@gmail.com

\section{Doi:10.5901/ajis.2015.v4n2p169}

\begin{abstract}
The aim of this study was to explore the experiences dhe perceptions of the parents of children with autism in relation to involvement in kindergarten and the impact on them. The qualitative method was used in the study. Semi-structured interview with open-ended questions was the instrument for data collection. Data collections were made possible by interviewing 21 parents of children with autism in Tirana, Albania. Through data analyses it came out that: (i) Most of children with autism attended kindergartens, in most cases private ones. The reasons that children with autism did not attend public kindergartens were because their staff didn't welcome them, they were considered as problematic, the highest number of children in the group, and a lack of specialized staff. For most parents private kindergarten remain the only option; (ii) The involvement of autistic children in kindergartens had a positive impact on them. Kindergarten had many influences especially on their child's socialization, on collaboration with others, on the structuring behavior, on the child cognitive development, on reducing aggression, increase cooperation between each other and in the ability to understand the context and to learn to work with others; (iii) The problem remains the lack of specific knowledge and information on autism from kindergarten staff.
\end{abstract}

Keywords: children with autism; kindergarten; parents

\section{Introduction}

Very few empirical investigations are focus on kindergarten transition for children with autism, however, there is a growing interest in early education practices for children with autism (Denkyirah \& Agbeke, 2010).

In Albania there are no scientific studies which have had their focus on the inclusion of children with autism in the kindergartens and the impact that it has on them. This important theme of social aspect is not addressed previously by Albanian researchers, therefore it was necessary that it should be explored. This study represents an attempt to bring scientific contributions in this field.

New data from Centers for Disease Control and Prevention (CDC, 2015) show that the estimated number of children identified with autism spectrum disorder (ASD) continues to rise, and the picture of ASD in communities has changed. About 1 in 68 children has been identified with autism spectrum disorder (ASD) according to estimates from CDC (2015). ASD is reported to occur in all racial, ethnic, and socioeconomic groups.

As the prevalence of autism has risen in recent years, the enrollment of children with autism spectrum disorders (ASD) in public school settings has increased as well but less is known about teacher attitudes toward including children with autism (Yeargin-Allsopp et. al., 2003). The increasing number of children on the autism spectrum requiring intensive supports provides an unexpected 21st century challenge to teachers and education systems (Coakley, 2010). The enrollment of children with ASD in public school settings has escalated in conjunction with the increased incidence of the diagnosis (Yeargin-Allsopp et. al., 2003). Characteristics associated with ASD can present unique challenges for both 
children and teachers in the classroom.

According to many researchers, positive teacher attitudes are one of the most salient variables influencing successful inclusion of children with disabilities in regular classrooms (Bender, Vail \& Scott, 1995; Buell, Hallam, GamelMcCormick \& Scheer, 1999; Chow \& Winzer, 1992).

According to Pianta, Cox, Taylor and Early (1999) current findings suggest that in general, schools and families engaged in a set of standard transition practices. Although teacher and parent involvement in transition preparation were high, practices were rarely individualized. Denkyirah and Agbeke (2010) surveyed preschool teachers in Ghana and the United States and asked teachers to endorse transition preparation practices that they viewed as important for supporting students with autism. They reported that all practices on the survey were important, with practices initiated early and involving multiple stakeholders (preschool, family, elementary school) as essential.

According to researchers (Fein \& Dunn, 2007; Sicile-Kira, 2004) inclusion of children with autism in education services is a very important factor to help and to develop them. Early treatment is very important for the future and lives of children with autism and also for their families (Kika, 2013).

In addition to cognitive and behavioral difficulties, children with disabilities may experience shifts in services and educational programming during transition, creating additional challenges for children and families (Fowler, Schwartz \& Atwater, 1991).

Pianta \& Kraft-Sayre (2003) emphasize that the extent to which these practices are implemented for students with autism and other disabilities is relatively unknown. Given that early school experiences are predictive of later school outcomes, fostering successful kindergarten adjustment emerges as an important education priority. Elementary school entry not only has symbolic meaning to children and families, but brings along new task demands. Comparisons between preschool and kindergarten activities, curriculum, and instruction suggest that students in kindergarten are expected to complete tasks more independently and rely on large-group instruction with less teacher support than preschool students (Le Ager \& Shapiro 1995; Rule, Fiechtl \& Innocenti, 1990).

According to Rimm- Kaufman \& Pianta (1999) in addition to heightened academic demands, evidence suggests that there is a dramatic decrease in parent-teacher communication in kindergarten. Furthermore, parent-teacher contacts in preschool may be more positive and less negative than parent-teacher contacts in elementary school. Thus, families may feel less involved and connected with their child's kindergarten teacher which may make transition more difficult for families. Although the majority of children transition to kindergarten successfully, a significant number of children experience difficulties.

At the age of 3 children are usually transitioned from th early intervention system to the public school system (Chawarska, Klin, \& Volkmar, 2008). Children with developmental disabilities may be at heightened risk for transition difficulties given their deficits in communication, problem-solving, and adaptive behavior (Mclntyre, Blacher \& Baker, 2006). According to Powers (2000) children with autism at preschool age can benefit from education programs which are provided in public facilities as well as private ones. Children with autism can receive specific services and can be involved in groups with children with normal development. Even in cases where the child is receiving services from a single provider (e.g., public school), it is still valuable to hold regular meetings with teachers (Chawarska et al., 2008).

Provision for special teachers and school facilities must recognize that children with autism need special care from preschool ages (Trevarthen, Aitken, Papoudi \& Robarts, 1996). Although teachers perceive students with disabilities to have more kindergarten entry problems than children with typical development (McIntyre et al., 2006). According to Powers (2000) the staff must have special knowledge to work with autistic children.

Also, the relation teacher-child is very important. The most commonly cited barrier to engaging in kindergarten transition practices reported by preschool teachers in the current study was lack of time. This finding is consistent with previous research (Rimm-Kauffman \& Pianta, 1999).

Practices such as school and home visits, communication with parents and preschool staff, transition planning meetings, and developing specific child interventions may be especially useful given that these practices increase communication between home, preschool, and kindergarten contexts (Pianta \& Kraft-Sayre, 2003). However, according to Powers (2000) now for children with autism there are more opportunities and options than have had existed previously.

The Convention on the Rights of the Child (CRC, Unicef, 1989) is the first binding instrument in international law to deal comprehensively with the human rights of children, and is notable for the inclusion of an article specifically concerned with the rights of children with disabilities. Article 24 reflects a clear commitment to the principle of inclusive education as a goal. Clearly, parents and the children themselves have to be partners in deciding the nature and intensity of such support and ways in which it can be reduced as both child and teacher become more confident and competent.

The Constitution of the Republic of Albania (1998) in Article 57 stipulates the equal right of all citizens to education, 
as well as in Article 59 the right to specialized education and integration in society of disabled people.

\section{Aim}

The aim of this study was to explore the experiences dhe perceptions of the parents of children with autism in relation to involvement in kindergarten and the impact on them.

\section{Research Methods}

The qualitative method was used in the study. According to Creswell (2003) qualitative research can be described as an effective method that occurs in its natural environment. Selection of method and instrument for data collection was carried out in copliance with the aim of the study. Bloomberg \& Volpe (2008) point out that the review of the literature identifies what it is known until now on the issue in the study, it helps to establishes the theoretical framework and presents a conceptual framework that governs the study.

The study had two research questions:

a. What are the experiences and perspectives of parents on the inclusion of children with autism in the kindergartens?

b. What are the experiences and perspectives of parents about the impact that involvement in kindergartens have on childrens with autism?

The instrument used in this study for data collection was the semi-structured interview with open-ended questions. The interview offers an opportunity to learn about events for which we were not able to observe when it occurs in their real environment (Tutty, Rothery \& Grinell, 2003). The questions of the interview were developed based on the literature of the field, based on the purpose of the study, as well as to the research questions. The interview was made up of three sections, which included the variables for which we were interested. The use of descriptive questions was a very important element encouraging the collection of qualitative data.

Data collections were made possible by interviewing of 21 parents of children (3-6 years old) with ASD. Their recruitment was conducted at National Centre for Growth, Development and Rehabilitation of Children, and Horizont Center in Tirana, Albania. Their selection and participation in this interview was conducted on the basis of criteria as age of the child. The interview process was conducted face to face, each of which lasted about an hour. Interviews were recorded to be analyzed later. The study sample consisted of 19 mothers and 2 father. Parents involved in the study had in common the age of the child with autism, 3-6 years. Also, they had their particular characteristics regarding age, residence, education, etc.

Qualitative data analysis made it possible to secure rich and wide information about the topic of the study. The process of data analyses was done manually with "cut and paste" method. The analytic procedure followed these phases: the data organization, categorization, identification of the themes, and codification of the data. The focus of qualitative research is on the process of understanding and interpretation (Denzin \& Lincoln, 2008; Lapan, Quartaroli \& Riemer, 2012).

The presentation of the results is associated with the descriptions of the participants, all in accordance with the ethical principles. Transcripts of the interviews are provided in order to support the interpretation of data. Descriptions of parents are an important tool in order to analyze the thematic of the study.

Consideration of ethical issues and the preservation of the identity of participants and their children has been a priority of the study. Despite that participation was entirely voluntary, in the study were followed basic principles of ethics. Giving informed consent has been the cornerstone of ethical considerations. Informed acceptance is more significant for qualitative research (Miller, Birch, Mauthner \& Jessop, 2012).

The process of collecting and processing data of the study was conducted in the period 09/02/2015-06/03/2015.

\section{Results}

Through data analyses, we found that:

\subsection{Experiences and perceptions of parents on the inclusion of children with autism in the kindergartens}

From the analysis of data collected from interviews showed that most children with autism attended kindergartens. 
"Therapists have advised us strongly to bring the child into regular kindergarten, and he goes regularly to kindergarten for three years now". (Parent 3)

"I have been taking my kid regularly to kindergarten for two years and I think it has been a wise choose". (Parent 12)

According to data collected parents reported that most of children's attended private kindergartens.

"I have taken my child to private kindergarten, more precisely I am obliged even though I don't have numerous economic possibilities". (Parent 9)

"Now it's been three years that my child is going to private kindergarten and I'm relatively satisfied with the work done there". (Parent 17)

According to most of parents the reasons that their children did not attend public kindergartens was because their staff didn't welcome children with autism, they considered as problematic children and impossible to work with them.

\begin{abstract}
"I tried several times to take my child to public kindergarten and I have changed two kindergartens, until I made up my mine and didn't try anymore". (Parent 14)

"I tried several time to take my child to public kindergarten, but besides he was not welcomed, there was time he was left totally alone, isolated from others so I had to withdraw him from the public kindergarten". (Parent 7)

"Public kindergarten have absolutely no conditions, large number of children in the group and don't have specialized staff to work with these kids". (Parent 16)
\end{abstract}

As the result of the above mentioned problems, the high number of children in the group, and a lack of specialized staff of public kindergartens, make for most parents that private kindergarten remain the only option.

"In the private kindergarten they pay more attention and care more about the child, it makes me feel more relaxed and more safe". (Parent 2)

"In the private kindergarten there are fewer children in the group, this means the teachers spend more time with my children and work more with him. Also having a low number of children's they pay more attention and include him more". (Parent 21)

"In private kindergarten my child was immediately welcomed and I think the threshold of acceptance in private kindergartens are higher in relation to public kindergarten, for more on private kindergartens the number of children in groups is smaller, it means that the teacher will work more with my child". (Parent 1)

According to data collected all parents reported that they had encountered numerous problems in the early stages of the involvement of the child in kindergarten, for many reasons, but the most importantly where the child's diagnosis. However, parents expressed that with time staff and children were well adjusted with each other and they did not had problems like they used to have in the beginning.

"In the beginning, when he went to kindergarten he didn't liked and had obvious difficulty in accordance with the environment or with other children, now no more. He likes to go to kindergarten now and goes regularly". (Parent 8) "At the beginning we faced many problems because the staff did not have information on how to work with such children. It happened that have been also the other parents that refuse because they did not want to interact with their children, they feared that maybe their children may imitate the behavior that he makes... Now there are no more such problems, he is welcomed". (Parent 19)

\title{
4.2 Experiences and perceptions of parents about the impact that kindergarten has on children with autism
}

All parents participating in the study said that the kindergarten had a positive impact on children also that is a difference from the previous period when they did not attend the kindergarten. According to them kindergarten had many influences especially on their child's socialization and also on collaboration with others, which they could not learn if they stay in home. The tendency of children diagnosed with autism is to stay alone, but by going to kindergarten they learn to interact with others and to socialize.

"Kindergarten definitely have a positive impact. In the beginning we did not think that it could be a good idea because we were scared for many factors, but now we are very pleased. It had influenced in a positive way because after being part of the kindergarten he had the biggest start-up and has learned to accept others, to spend time with them and have learned to interact. This is very positive because before he had required just to stay home alone, all the time". (Parent 4)

"By being part of the kindergarten he has become quieter and has learned to share his toys and be less aggressive towards others, this is very positive because in the beginning it was not so quiet but it has been very frustrated". (Parent 15) 
According to data collected parents reported that kindergarten have had positive effects on the structuring behavior, on the child cognitive development, on reducing aggression, increase cooperation between each other and in the ability to understand the context and to learn to work with others.

"Of course, kindergarten have had very positive impact. Now he has a structured behavior in relation to the previous period. In the kindergarten he has learned to interact with others and has learned to work in a group and be quiet and not aggressive. These has very important meaning for us". (Parent 6)

"I think the kindergarten is a very powerful component and has helped a lot, because he is part of different activities, different exercises and he interacts more and regularly with other children". (Parent 11)

\subsection{Experiences and perceptions of parents regarding the relationship with the staff of the kindergarten}

According to the majority of the parents, after the first moment the child enters in kindergarten, the kindergarten staff was perceived as more cooperative, more sympathetic and sensitive. Participants in the study reported that the staff has difficulties in their work due to the sensitive diagnosis that they children had. Also, parents highlighted the lack of knowledge and lack of specialization of the staff, even they reported that they had good desire to work with these children.

"We have very positive relationship with the staff, they are careful and very sensitive even though they do not have the knowledge or skills to work with this target group, but they have great desire and they are very careful". (Parent 18)

"I think that the lack of information has a significant impact however they make maximum efforts and are very dear and careful with children". (Parent 10)

\section{Discussion}

This section presents a discussion about the issues raised in this study. The discussion compares the results of the study with those of other studies. For that reason the researchers have developed a logical interpretation of the main topics. Literature review helped to be effective. Discussing the results of the study takes into account many factors such as the age of child, severity of the disease, family culture, family resources, services offered, etc.

Results showed that most children with autism attended kindergartens. Parents reported that most of children's attended private kindergartens. The reasons that their children did not attend public kindergartens was because their staff didn't welcome children with autism and they were considered as problematic, the highest number of children in the group, and a lack of specialized staff. For most parents private kindergarten remain the only option. Results on the issue showed a higher involvement of children with autism in the kindergartens, which reported and Yeargin-Allsopp et. al., (2003). The difference was in the type of kindergarten, public and private.

Study results also showed that parents had encountered numerous problems in the early stages of the involvement of the child in kindergarten. However, parents expressed that with time staff and children were well adjusted with each other and they did not had problems like they used to have in the beginning. This is consistent with what many other researchers point out that positive teacher attitudes are one of the most salient variables influencing successful inclusion of children with disabilities in regular classrooms (Bender, Vail \& Scott, 1995; Buell, Hallam, Gamel-McCormick \& Scheer, 1999; Chow \& Winzer, 1992).

Involvement of children in kindergartens had a positive impact on them. According to the results of the study kindergarten had many influences especially on their child's socialization, on collaboration with others, on the structuring behavior, on the child cognitive development, on reducing aggression, increase cooperation between each other and in the ability to understand the context and to learn to work with others. This finding of the study is consistent with that other authors believes about the importance of early involvement in educational services for the development of children with autism (Fein \& Dunn, 2007; Kika, 2013; Sicily-Kira, 2004).

Also the study showed that the problem remained at the lack of specific knowledge on autism from kindergarten staff. This result is consistent with that other authors believes (McIntyre et al., 2006; Powers, 2000).

\section{Conclusions}

In conclusion we can say that: (i) Most of children with autism attended kindergartens, in most cases private ones. The reasons that children with autism did not attend public kindergartens were because their staff didn't welcome them, they were considered as problematic, the highest number of children in the group, and a lack of specialized staff. For most parents private kindergarten remain the only option. After those problems in the early stages of the involvement of the child in kindergarten, staff and children were well adjusted with each other and they did not had problems like they used 
to have in the beginning; (ii) The involvement of autistic children in kindergartens had a positive impact on them. Kindergarten had many influences especially on their child's socialization, on collaboration with others, on the structuring behavior, on the child cognitive development, on reducing aggression, increase cooperation between each other and in the ability to understand the context and to learn to work with others; (iii) The problem remains the lack of specific knowledge and information on autism from kindergarten staff.

We think that some proposals may be necessary for a higher involvement of children with autism not only in private kindergartens but also in public kindergartens, for example: Greater support and assistance of the staff of the kindergarten for children with autism, especially public ones; training of personnel to work with these children, individual and specific programs for children with autism, etc.

\section{References}

Bender, W. N., Vail, C. O., \& Scott, K. (1995). Teachers' attitudes toward increased mainstreaming: Implementing effective instruction for. Journal of Learning Disabilities, 28 (2), 87-94.

Bloomberg, L. D., \& Volpe, M. (2008). Completing Your Qualitative Dissertation: A Roadmap from Beginning to End. California: Sage Publication.

Buell, M. J., Hallam, R., Gamel-McCormick, M., \& Scheer S. (1999). A survey of general and special education teachers' perceptions and inservice needs concerning inclusion. International Journal of Disability, Development and Education, 46 (2), 143-156.

Centers for Disease Control and Prevention (CDC). (2015).

http://www.cdc.gov/ncbddd/autism/data.html.

Chawarska, K., Klin, A., \& Volkmar, F. R. (2008). Autism Spectrum Disorders in Infants and Toddlers. New York: The Guilford Press.

Chow, P. \& Winzer, M. (1992). Reliability and validity of a scale measuring attitudes toward mainstreaming. Educational and Psychological Measurement, 52, 223-238.

Coakley, M. (2010). State guidance documents for young children with autism spectrum disorders: Content and comparison. Infants \& Young Children, 23, 145-164.

Creswell, J. W. (2003). Research design: Qualitative, quantitative, and mixed methods approaches (2nd ed.). Thousand Oaks, CA: Sage.

Denkyirah, A. M., \& Agbeke, W. K. (2010). Strategies for transitioning preschoolers with autism spectrum disorders to kindergarten. Early Childhood Education Journal, 38, 265- 270.

Denzin, N. K., \& Lincoln, Y. S. (2008). Strategies of qualitative inquiry (3rd ed.). Thousand Oaks, CA: Sage.

Fein, D., \& Dunn, M. A. (2007). Autizmi në klasën tuaj: Udhëzues i përgjithshëm i mësuesit për nxënësit me çrregullime të spektrit të autizmit. Bethesda: Woodbine House.

Fowler S. A., Schwartz I., \& Atwater J. (1991). Perspectives on the transition from preschool to kindergarten for children with disabilities and their families. Exceptional Children, 58, 136-45.

Kika, M. (2013). Zhvillimi i fëmijës. Tiranë: Mediaprint.

Kuvendi. (1998). Kushtetuta e Republikës së Shqipërisë. Tiranë.

Lapan, S. D., Quartaroli, M. T., \& Riemer, F. J. (2012). Qualitative Research: An Introduction to Methods and Designs. San Francisco: Jossey-Bass.

LeAger, C., \& Shapiro, E. (1995). Template matching as a strategy for assessment of and intervention for preschool students with disabilities. Topics in Early Childhood Special Education, 15 (2), 187-219.

McIntyre, L. L., Blacher, J., \& Baker, B. L. (2006). The transition to school: Adaptation in young children with and without intellectual disability. Journal of Intellectual Disability Research, 50 (5), 349-361.

Miller, T., Birch, M., Mauthner, M., \& Jessop, J. (2012). Ethics in Qualitative Research. Thousand Oaks, CA: Sage.

Pianta, R., Cox, M., Taylor, L., \& Early, D. (1999). Kindergarten teachers' practices related to the transition to school: Results of a national survey. The Elementary School Journal, 100 (1), 71-86.

Pianta, R., \& Kraft-Sayre, M. (2003). Successful kindergarten transition: Your guide to connecting children, families \& schools. Baltimore, MD: Paul H. Brookes Publishing Co.

Powers, M. D. (2000). Fëmijët me autizëm: Udhëzues për prindërit. (Botimi i dytë). Bethesda: Woodbine House.

Rimm-Kaufman, S.E., \& Pianta, R. C. (1999). Patterns of family-school contact in preschool and kindergarten. School Psychology Review, 28 (3), 426-438.

Rule, S., Fiechtl, B., \& Innocenti, M. (1990). Preparation for transition to mainstreamed post-preschool environments: Development of a survival skills curriculum. Topics in Early Childhood Special Education, 9(4), 78-90.

Sicile-Kira, C. (2004). Autism Spectrum Disorders: The Complete Guide to Understanding Autism, Asperger's Syndrome, Pervasive Developmental Disorder, and Other ASDs. New York: The Berkley Publishing Group.

Trevarthen, C., Aitken, K., Papoudi, D., \& Robarts, J. (1996). Children with Autism:Diagnosis and Interventions to Meet Their Needs. London: Jessica Kingsley Publisher.

Tutty, L. M., Rothery, M. A., \& Grinell, M. R, Jr. (2003). Kërkimi cilësor për punonjësit social: Fazat, hapat dhe detyrat. Tiranë: Dituria

Unicef. (1989). Konventa mbi të drejtat e fëmijëve. Tiranë

Yeargin-Allsopp, M., Rice, C., Karapurkar, T., Doernberg, N., Boyle, C., \& Murphy, C. (2003). Prevalence of autism in a US metropolitan area. Jama, 289 (1), 49-55. 